RESENHA 


\title{
ARAÚJO, Denise Lino de. Enunciado de atividades e tarefas escolares: modos de fazer. Olinda: Livro Rápido, 2014.
}

\author{
Elcemina Lúcia Balvedi Pagliosa
}

\author{
Professor Doutor em Linguística Aplicada \\ Universidade Regional Integrada do Alto Uruguai e das Missões - URI Erechim
}

Data do recebimento: 06/09/2021 - Data do aceite: 04/10/2021

A professora Dra. Denise Lino de Araújo, da Universidade Federal de Campina Grande - Paraíba, leciona nos cursos de graduação e pós graduação. É pós doutora em Educação pela FAE/UFMG, onde trabalhou junto ao Grupo de Estudos e Pesquisas sobre Currículo e Culturas. Dedica-se ao ensino, pesquisa e extensão, tendo como foco o ensino do português como língua materna, em especial no Ensino Médio.

Nessa obra, especialmente, Denise Lino se vale de rica experiência como professora e pesquisadora, articulando seus conhecimentos com colegas de universidade, acadêmicos de vários níveis da educação superior, orientandos do Programa de Educação Tutorial - PET, entre outros.

A professora doutora Lívia Suassuna, da Universidade Federal de Pernambuco, oportunamente, assim se refere à obra em questão, no seu Prefácio: "Denise Lino, então, assume, com este livro, o compromisso de contribuir com a formação de professores de Língua Portuguesa na medida em que mostra questões e enunciados, decifra seus processos de elaboração, compara-os classifica-os, num exercício teórico-metodológico indispensável a qualquer docente que queira avaliar com rigor, transparência e pertinência."
A autora apresenta sua proposta em quatro capítulos, além da introdução, considerações finais e referências, em 147 páginas.

Na INTRODUÇÃO há a constatação de que não se tem ensinado o licenciando a formular atividades e, nem mesmo, demonstrado a vinculação entre a teoria defendida e os exercícios que a materializam. Situa essa obra como destinada a professores de Língua Portuguesa com o objetivo de descrever a elaboração de enunciados das atividades de leitura, análise linguística e de produção textual.

O Capítulo 1, denominado "ATIVIDADES E TAREFAS NA AULA DE LÍNGUA PORTUGUESA" a autora faz uma oportuna distinção entre atividades e tarefas. Ao fundamentar suas colocações em Matêncio, Bloom e Moretto, depreende-se que as atividades se prestam a duas grandes finalidades: a primeira - fixação da aprendizagem - procedimento de ensino que pode ser realizado com ou sem o monitoramento compartilhado do professor; a segunda - verificação da aprendizagem, atividade sem o monitoramento do professor, se prestando, normalmente, à atribuição de notas ou conceitos avaliativos.

Nesse primeiro capítulo, chama atenção a alusão à taxonomia de Bloom para a definição 
dos níveis de complexidade que uma atividade deverá apresentar: básico, intermediário e avançado. A autora reconhece que essa taxonomia se fixa apenas em objetivos cognitivos e operações mentais e não focaliza importantes aspectos interacionais entre professor e aluno, bem como aspectos socioculturais.

A autora, no Capítulo seguinte - "A SEQUÊNCIA INJUNTIVA NO ENUNCIADO DE ATIVIDADES E DE TAREFAS”, inicia afirmando que na sequência injuntiva dá-se uma ordem, apresenta-se um roteiro de trabalho, sugere-se a realização de um procedimento, sempre guiando o interlocutor. Cita Rosa ao mencionar três tipos de comandos que caracterizam as sequências injuntivas: os obrigatórios, os alternativos e os opcionais. Ressalte-se a oportuna relação feita entre essas três sequências injuntivas com as questões propostas no Exame Nacional do Ensino Médio - ENEM. Faz menção, ainda, a alguns problemas que devem ser evitados na formulação de questões, tais como: apresentar primeiro o texto para só depois formular o enunciado; orientar a proposição no sentido do que NÃO se pode concluir. Recomenda o uso do imperativo e com verbos cujos parâmetros de avaliação estejam bem claros, como enumerar, por exemplo.

Destaque deve ser feito a dois itens tratados nesse capítulo: "A sequência injuntiva nos enunciados de atividades de leitura e de análise linguística" e "A sequência injuntiva nos enunciados de atividades de escrita". No primeiro faz uma importante colocação quanto a dois comandos das sequências injuntivas usados nas provas: os simples e os regulados por modos de ação. Os exemplos apresentados permitem o bom entendimento e uso desses comandos. Na sequência injuntiva das atividades de escrita julga importantes as atividades que apresentem modelos para se ensinar como se constrói um texto quando temos um leitor presumido e outros aspectos ausentes para o aluno. Ressaltem-se as colocações decorrentes da análise de duas coleções de livros didáticos, aprovadas pelo Programa Nacional de Livros Didáticos PNLD - em 2008. Antes de iniciar o capítulo seguinte, duas colocações chamam a atenção: dar ao aluno, ao escrever um texto, a perspectiva de torná-lo público, pois isto leva a ter o que dizer, para quem dizer e como dizer; ser o professor o primeiro leitor, revisor e crítico do texto do discente.

"QUESTÕES DISCURSIVAS E QUESTÕES DE MÚLTIPLA ESCOLHA EM ATIVIDADES DE LEITURA E DE ANÁLISE LINGUÍSTICA" é o título do Capítulo 3. Pontua que diferentes gêneros textuais requerem diferentes atividades de compreensão. Não se lê um texto literário da mesma forma que se lê uma notícia. Considera, também, a compreensão como um primeiro nível de leitura, que leva ao segundo, obrigatoriamente associado a ele, que é a interpretação. Dois grandes subitens são tratados nesse capítulo: níveis de leitura e questões de múltipla escolha.

No primeiro deles afirma que três níveis de leitura devem ser atingidos pelo leitor proficiente - explícito, implícito e metaplícito. Fazendo considerações muito oportunas acerca de cada um deles. Vai adiante tratando das questões discursivas, abordando-as como objetivas, inferenciais e avaliativas. Além da diferenciação de cada uma delas, importante análise de questões de livros didáticos, é aqui apresentada.

No subitem Questões de Múltipla Escolha, além da definição do que essas questões significam, há uma farta exemplificação e análise das mesmas, relacionando-as a exames do SAEB, ENEM e outros concursos como os vestibulares. Dentro desse subitem é definido e exemplificado o Teste Cloze e as Questões de Duas Seções. Tanto uma quanto a outra colocam em jogo a competência leitora dos alunos. 
Denise Lino de Araújo, no Capítulo 4, último da obra, trata de "QUESTÕES DE MÚLTIPLA ESCOLHA SEGUNDO O MODELO DO ENEM". Em dez bem apropriados exemplos de questões do ENEM, analisa-os de acordo com os princípios formulados nos três primeiros capítulos desse livro, acrescidos do referencial teórico de alguns linguistas. Entendo como muito significativa a análise feita e de substancial importância para o professor, especialmente para o de Ensino Médio.

Ressalto, nas Considerações Finais, o que a própria autora diz: “Acreditamos que ler bem é muito mais do que saber identificar o tema, a tese ou o eu-lírico do texto; é também ver como o autor o/a enuncia, que efeitos de sentido cria, como usa os recursos linguísticos para seus propósitos".

Enfim, por tudo o que foi dito, recomendo aos professores de todos os níveis, a leitura dessa obra. Formular questões não se faz, apenas, repetindo o que outros fizeram. Há que se compreender o que se pergunta, por quê se pergunta, a quem se pergunta e em que contexto inserimos as questões. Ensino e avaliação tem propósito e requerem ciência e preparo. 
